\title{
Whither Progressive Urban Futures? Critical Reflections on the Politics of Temporality in Asia
}

\author{
Hyun Bang Shin ${ }^{1}$, Yimin Zhao² and Sin Yee Koh3
}

1. Hyun Bang Shin is Professor of Geography and Urban Studies in the Department of Geography and Environment and Director of Saw Swee Hock Southeast Asia Centre at the London School of Economics and Political Science. E-mail: h.b.shin@lse.ac.uk

2. Yimin Zhao is Assistant Professor in Urban Planning and Management in the School of Public

Administration and Policy at Renmin University of China. E-mail: zhao.y@ruc.edu.cn

3. Sin Yee Koh is Senior Lecturer in Global Studies in the School of Arts and Social Sciences at the

Monash University Malaysia. E-mail: koh.sinyee@monash.edu

\begin{abstract}
Compressed development experiences, especially in Asia, have translated into expectations for 'fast cities' where time and space are compressed to materialise 'real' Asia experiences. However, what does 'fast urbanism' mean for those who see Asian cites as reference points? Moreover, what does 'fast urbanism' mean for those who have living memories of such fast-paced development, and how might this be different for their future generations? This intervention addresses these two questions by reflecting on the politics of temporality, calling for critical attention to the ideological imposition of 'fast' development in Asia and beyond. We argue that the 'Asian speed' of development was enabled in specific historical and geographical conjunctures, which entailed the appropriation of individual and collective aspirations through the invention of a certain kind of futurity and in so doing, consolidated of local politico-economic structures that displace both the present and the future.
\end{abstract}

Keywords: fast urbanism; condensed development; embodied temporality; urban futures; urban politics; Asia

\section{Introduction}

Asian ${ }^{1}$ economies such as South Korea, Taiwan, Hong Kong and Singapore were often referred to as 'tiger' economies for their fast-paced development and growing potential to catch up with and even surpass the Western economies. For instance, South Korea's economy, led by an authoritarian (developmental) state, took just about 25 years to experience a five-fold increase in real GDP per capita from 1966 when its economy was taking off (Dunford and Yeung, 2011). Such phenomenal speed exemplified by two-digit economic growth rates over many years was shared with other Asian economies including mainland China in the second half of the twentieth century. Their experiences of fast-paced growth can be considered as compressed or condensed, especially when compared with the experience of more advanced economies such as the UK and the USA (taking 160 years and 100 years, respectively, to achieve a five-fold increase in real GDP per capita). Set within the context of these Asian economies' rapid economic growth and development, cities as sites of production and seats of political power have also expanded and developed rapidly.

Concrete experiences of urban development in Asia have also grounded the possibility of 'mobile urbanism' and 'policy mobility' (McCann and Ward, 2011). These developmental experiences are packaged as a model of urban development and then increasingly become a reference point for other countries and cities that are lured by a pre-packaged prescription to be another 'Shanghai', 'Singapore', 'Shenzhen' or 'Seoul'. The temptation to transplant urbanism from Asian cities is in part due to the temporality of such developmental experiences, which were all compressed into less than one generation ( $<30$ years). The 'Asian Model' is hence seen as a more successful model compared to the experience of the UK or the USA, which took multiple generations.

\footnotetext{
${ }^{1}$ In this paper, 'Asia' is largely referring to East and Southeast Asia, bearing in mind that such regional boundary making is relative and to some extent, artificial, and that 'Asia' may come with diverse definitions (see Sidaway et. al., 2016).
} 
Compressed development experiences translate into expectations for a 'fast policy transfer' or 'fast cities' (Datta and Shaban, 2017) that would compress time and space to materialise 'real' Asian experiences. While such fast-paced development of Asian economies is often a source of admiration and inspiration by many others in the global South, what does the 'fast urbanism' mean for those who see Asian cites as reference points? What does it also mean for the people who live with the memory of such fast-paced development? Our intervention deals with these two key questions by reflecting on the politics of temporality. We now turn to the first question, highlighting the importance of conditions of development and how they are hard to be replicated.

\section{Limits to replicating the success of 'Asian economic miracle'}

Capitalism in general works towards increasing the speed of production (and consumption) such as the re-working of various regulations, institutional designs, planned obsolescence of commodities to create new demand, financial innovations and so on. While all of these efforts can be considered as the traces of global capitalist innovations during the modern history of capitalism, the more recent neoliberal twist has worked to ensure such efforts by capital and ruling classes produce profit-maximising outcomes by lowering the barriers to the mobility of capital and the flexibility of labour.

The 'strength' of the Asian model of condensed development and 'fast urbanism' is the ability of the state to shape the conditions of accumulation in a time-efficient manner by quelling resistance and nurturing the expansion of its own 'social bloc' (armed forces, police, civil servants, businesses, and middle classes) (Shin, 2018, 2019; Shin and Zhao, 2018; see also Chua, 2017, Doucette and Park, 2019, Zhao 2017). This is indeed the (developmental) state-led version of what David Harvey (1989) coined as 'time-space compression' (built upon Marx's thesis on 'appropriation of space by time' in Grundrisse). The ways in which fixed assets accumulation has been carried out in a timely manner (or to be more precise, the high speed of producing the built environments) reflect the nature of capital that tirelessly works towards speeding up various circulations of itself. In this regard, the lure of shaping development policies by modelling after Asia may be too big a temptation to resist.

Replicability of findings, a key criterion for laboratory scientists, rests on the recreation of the same experimental conditions. However, on-going and established discussions about policy transfer in general fall short of taking into consideration the factors conditioning development in specific contexts. Those who advocate the adoption of 'developmental model' turn blind eyes to the complexities, overly focusing on what produced investment efficiency and, in turn, ignoring the contextual significance of the role of the state in deploying both human and nonhuman resources. What used to be the dominant discourse of the 'developmental state' fell prey to the 'methodological nationalism', failing to identify how geopolitical economic conditions such as the Cold War shaped the conditions of the 'Asian (economic) miracle' (see Glassman and Choi 2014 for a more detailed interrogation). The 'developmental state' argument also suffered from 'methodological (central) statism' that gave supremacy to the bureaucratic functioning of the (central) state mechanism without giving adequate attention to regional players (Gimm, 2013), and to how the state is positioned vis-a-vis the society and the capital (Shin, 2018). More recent work further emphasises the role of the urban in conditioning development where the 'developmental state' was able to perform its power (Doucette and Park, 2019). All these suggest that the conditions of development do not simply hinge upon such conducts as reforming governance or practising the rule of law. The 'Asian speed' of development was enabled in specific historical and geographical conjunctures, which could be hardly replicated elsewhere if possible at all.

\section{The temporal mode of governance}

"Quick, quick, quick: that is Korea" was reportedly a proud remark by a retired South Korean politician who reflected on the economic success of the country between 1960 s and $1990 \mathrm{~s}$ (Mallaby, 1995). As he proudly stated, "[w]e built a lot in 20 years, as much as other countries built in 100", which could be attributed to the speed of resource mobilisation that spurred 
economic growth. South Korea during the times of such condensed development pursued a proactive investment in infrastructure, spearheaded by the construction of Gyeongbu Expressway that was the first motorised highway to connect Seoul with Busan. Such drive of productive investment was also reflected in the strategies of large conglomerates that were investing heavily and courageously in production facilities and infrastructure. For example, Hyundai made the decision to embark on the shipbuilding industry when there was practically no dock available. And, all such conducts were accompanied by the enactment of certain work ethics that depended on appallingly long working hours at the expense of family life and personal safety. At the personal level, this lifestyle is vividly embodied in the theme song of the renowned Sae-Ma-Eul Movement ('New Village Movement'), promoted under the authoritarian Park Chung-Hee regime. It started as follows:

The bells of dawn ring, a new morning has broken

Let us all wake up and cultivate Sae-Ma-Eul

The emphasis on speed is also evident in mainland China, which in turn induces a temporal mode of governance. "Time is money, and efficiency is life." This famous slogan, first appeared in Shenzhen nearly four decades ago, was once seen as the signal of China's market reform. This reform was supposed to help the country move beyond the planned economy and (for many commenters) the authoritarian regime. It has now been widely agreed, however, that this reform, together with its neoliberal nature (c.f. Harvey, 2005), is not at odds with a strong party-state that could helm the 'centrality of planning' (Wu, 2015; see also $\mathrm{Wu}, 2018$ ). Indeed, we have been witnessing the rise of what Lee (2018) calls "Global China" that is backed by this state, which re-gains its power and legitimacy (read: life) through the ethos of efficiency and velocity embodied in the aforementioned slogan.

What is qualitatively different, perhaps, is that every aspect of the Chinese society is now impelled to perform that slogan/temporality to its extreme. IT workers, for instance, are being pushed to work in the "996" style (from 9am to 9pm, six days a week) which for sure does not comply with the needs of work-life balance; but Ma Yun, the founder of Alibaba Group who hires armies of IT workers, remarked that being able to work in the "996" style is a blessing rather than a curse (Yang, 2019). As work bleeds into and overtakes personal and family time, people rely on food delivery services as they do not even have time to go out for lunch or dinner. The food delivery business makes profits in the margin of billions of Yuan annually, but at the cost of deliverymen's lives - most of whom are rural-urban internal migrants. Pushed to be quicker and quicker, and penalised for delays clocked in seconds, these deliverymen pay no attention to pedestrians, traffic lights, falling trees, flooding streets and, in the end, their own lives (Cheng, 2019).

In all these instances, the state is both omnipresent and absent. While the state exercises its power to remain dominant for its political legitimacy, it also rules from afar (Zhang and Ong, 2008). The absence of state regulations is insightfully captured by Ananya Roy $(2005,2009)$ as the signifier of an "informal" mode of governance in her discussion on India's planning regime. In China, this comment could be further developed with a connotation to be identified in consistent concerns of the speed. Following "an anthropology of anticipation" (Obarrio, 2012; cited in Roy, 2016, p. 319), we could easily recognise that the obsession with speed and efficiency is implicitly yet widely shared by the state and non-state actors (Shin \& Zhao, 2018). The politics of futurity is rendered one-dimensional, with the incorporation of everyone's memories, dreams, desires, times and lives into the state agenda as the kernel - what the partystate would label as the "Chinese Dream" (Xi, 2012). In the official discourses of such a promising future, which is (and should be) collective, a gap is generated simultaneously between the collective good and individual sufferings, where the latter is supposed to be shouldered silently and in docility, in order to make way for the former.

Here we can further identify a new connotation of informality from the view of temporality, which could be coined as the temporal impossibility of justice (cf. Roy, 2009, where she discusses "the territorial impossibility of governance"). This impossibility conditions Chinese experiences of compressed and condensed development, similar to that in many other Asian economies, while at the same time disables potential collective actions in effecting social change. 
Masked by the shared ethos on temporality among the state and the people, the cunningness of brutal capitalism looms large. It disguises itself in various tactics of capital accumulation (and conveniently overlooks individual suffering) with specific narratives of (nationalistic) development and futurity. This, in turn, renders possible new techniques of governance (or nongovernance) that are more temporal (or at least temporality-related) than territorial - in this sense, temporality-shaping in China becomes a new state project, one that plays a critical role in disciplining people and impelling and monitoring "development." This shaping of temporality is remarkable not only for its power in affecting 1.4 billion people's daily lives, but also because it reveals vividly the (often invisible) cost of the widely acclaimed and celebrated "Asian Urbanism," "Asian Century" or the so-called "Asian Miracle."

\section{The ideological imposition of futurity of development}

Ananya Roy (2016: 318) also argues that, in Asia, thinking about the "politics of futurity" allows us to question "how futurity itself becomes a mode of governing." The phenomenal two-digit growth rates that Asian economies often experienced during their economic take-off (e.g., 1960s-80s in South Korea, and 1980s-90s in mainland China) were embodied experiences of the generations who lived through the era. This pace of development is often captured colloquially in an expression known as 'GDP-ism' that gives supremacy to the macroeconomic gains, creating a numbers game when it comes to industrial policy-making. ${ }^{2}$ Here again, the past glory acts as constraints, forcing Asian economies to attempt to replicate such high-paced accumulation of inputs, even though real economies are hard to comply with such high-barred aspirations.

Under the condensed economic development, absolute poverty was reduced and the middleclass expanded. The rise of the middle class in Asia can be seen not as the act of the invisible hand' but of the state that proactively nurtured its rise so that the middle class could become another cornerstone (in addition to the civil servants, the military and the police force) for the construction of hegemonic ideology that justified the state legitimacy and governance from afar (Zhang and Ong, 2008; see Chua, 1997 and Teo, 2011 for the Singapore case). This is evidenced vividly in Singapore's obsession with planning for the future, a practice that makes the country survive and thrive in the fierce competition for foreign investment while at the same time maintaining the 'dictatorship of the middle class' (Rodan, 1992) and the state legitimacy at the expense of civil liberties (Chua, 2017). The obsession that drives the city-state to plan for and prevent 'doomsday' adds pressure onto the entire society, driving the city-state to launch numerous infrastructure projects with the ambition of putting the new in place so that they can be ready for use whenever necessary in the near future. Such state-led provision of infrastructure is also considered as part of productive investment that would sustain the economy through the accumulation of inputs.

"Eventuality," a term coined by Simone and Pieterse (2017), is at work here. The idea of "fast urbanism' was born out of the condensed economic growth with experiences in cities of primacy (e.g., Beijing, Hong Kong, Seoul, Singapore and Taipei, among others). It continues to direct contemporary urban policies today but in a new way that invokes a futurity (eventuality) of development. This is built on the constant referencing to past achievements, which are no longer replicable but yet still deployed to dictate (and in a sense displace) the present. As being evidenced in the aforementioned case of the "Chinese dream," various governments, both central and local, project the future as a superior alternative to the current conditions of living. They claim that the country, the nation or the society should move towards certain goals and justify their claims with their previous abilities of achieving seemingly impossible missions. Individuals may also mimic the practices of their governments, projecting their aspiration of upward mobility against the future yet to come (see Figure 1).

\footnotetext{
2 Indeed, China's massive stimuli package that included huge amounts of state-mobilised investment in expanding nation-wide high speed rail network was in part an extension of GDP-ism to overcome the damage inflicted by the global financial crisis of 2008/09 and to ensure numbered growth targets were to be achieved.
} 
Figure 1: A government poster in Beijing. The slogan reads: "Each individual is a witness, creator and builder of a new era" (Photographed by Yimin Zhao, 2019)

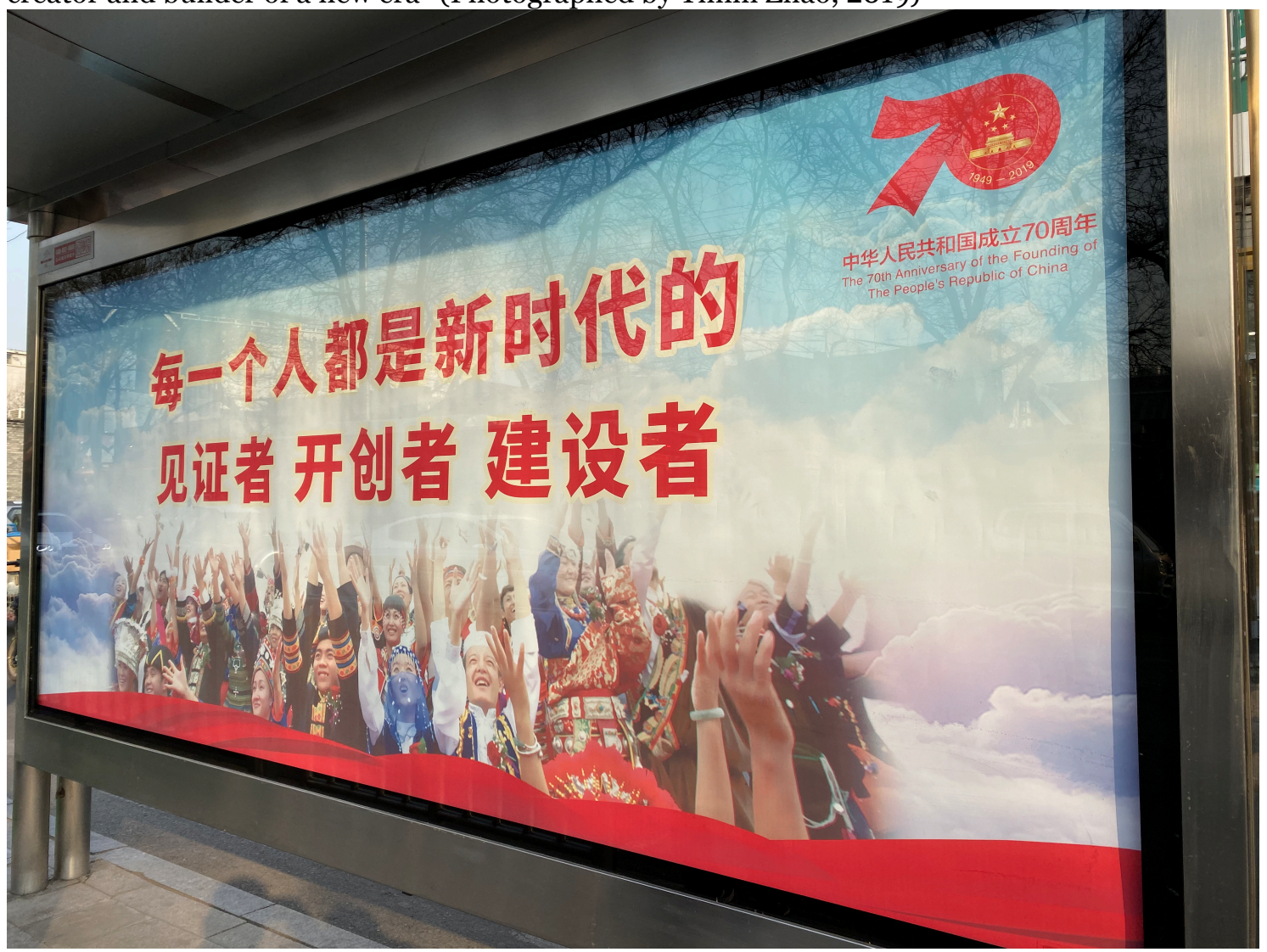

Yet, it is worrying to see the constant (re)casting of the present into a future that never quite materialises in the manner envisioned. First, these urban futures are often narrated (or 'sold') through rose-tinted glasses. The resulting built forms, however, may be distant shadows of their artistic impressions circulating in glossy marketing collaterals. Second, in the haste to "get there first, ahead of everybody" and to produce material forms (e.g., skyscrapers, elite enclaves, new cities, mega projects) that support further legitimisation, careful and considered planning processes can be compromised or re-written. Third, and relatedly, the rush for urban-led capital accumulation contributes to the further exacerbation of existing inequalities between those who own the means of urban production and those who do not. 'Fast urbanism' brings forth quicker and larger profits for developers, landlords, conglomerates and businessmen, who can subsequently multiply their assets and profits at greater speeds. By contrast, the property-less who have not managed to get on the bandwagon of 'fast urbanism' at the right moment becomes more and more marginalised and excluded.

\section{Intergenerational and geographical differences in embodied temporalities}

While we set aside the question of how 'fast urbanism' of Asian economies can be replicated in another space and time, two more pressing questions we raise here are to think about the major conflicts of embodied temporalities across generations and geographies. The first question involves an examination of how each generation is to face their own challenges in terms of thinking about the urban future. This is a critical issue because such imaginaries of urban futures (based on their embodied perception of the speed of development) would influence the potential forms of social movements and progressive urbanism. The second question, that is, differences in temporalities across geographies, requires us to look further into the issue of uneven development (Smith, 1984). 
The 'Asian Miracle' is a lived experience of older generations (especially in the "Tiger" economies), who were able to live through high speed of economic and urban development, which allowed them to have stable access to jobs and housing and enabled them to carry out social reproduction without resorting to social welfares. In the enduring context of 'productivist welfare' (Holliday, 2000) that emphasises intra-family and intergenerational pact of mutual support, the 'success' story of economic-miracle generation becomes a reference point that constrains behaviours of current (and future) generations, whose life chances are much more delimited. This might become a new source of conflicts between generations - between older generations who benefited from and hence embraced fast-paced development and younger precarious generations who are cut off from opportunities in economies of recession (and occasionally, contraction).

Older generations would impose their beliefs unto younger ones, arguing that if they worked hard and retained the principle of frugality, they would succeed just like their parents did. Such accusations are not fair because we already see how and to what extent the younger generations now live a life of the precariat (Standing, 2001). Such inter-generational conflicts have significant impact on how we could imagine the right to the city, the future of cities, and how urban social movements are to be shaped. Things can be quite radically envisaged in the Global East 3 where condensed urban development had been four to six times faster than their counterparts in the industrialised West. When a generation has witnessed time-compressed modernisation of the country (in terms of infrastructural upgrading and urban development) and embodied improvement of income and poverty alleviation, this becomes a new standard and reference point for thinking about the present and the future. However, the temporality of younger and future generations might be quite different. The goal of equitable economic development under capitalism, therefore, often bears the potential to become inherently rhetorical and hence antagonistic.

Next, we consider the geographical differences. As economies organise around urban agglomerations and conditions of development become unevenly distributed, cities, provinces and countries face an uneven pace of development too. Economically advanced cities and regions constantly compete for more supports in order to make sure high-paced development continues, even if this worsens spatial inequalities. Carolyn Cartier's (2013) work on uneven development in China is illustrative of how the temporality of development in one region can act as constraints on other regions. Such competitions are also encouraged by the central government for economic and political concerns. For example, in a report issued by China's National Development and Reform Commission in 2008, where plans for the development of the Pearl River Delta region were laid out, we can see immediately the switching of narratives between a praise of the region's past achievements and its lack of competitive edge at present. This in turn enables a concrete tactic of the region to ask for more fiscal and institutional supports from the central government. Such discourses may be replicated by many other local governments that aim to justify high-paced development, becoming what Chien and Woodworth (2018) refer to as the 'urban speed machine'. And in this vein, an urban or regional temporality comes into shape, which corresponds to their position in the uneven pace of development.

However, there are other cities and regions that would fail to be incorporated into the expanding circuits of capital accumulation and fail to win the national/global competitions for investment. Such places are often heavily dependent on central government subsidies for the provision of basic services. Some of them end up where they are after going through 'deceleration' (e.g., rustbelts or mining towns that have gone defunct), while some others might have always been marginal due to politico-economic and/or geographical constraints. These places are governed by temporalities that are different from those so-called 'global/world cities.' In other words, they are excluded from the process of 'time-space compression', yet they are affected by the process inadvertently. In China, small- and medium-sized cities and counties in central and western regions are always exposed to developmental imperatives of catching up with cities in the coastal region, where the country's 'get rich first' reform and Open Door policies produced

\footnotetext{
${ }^{3}$ Here broadly defined as to include South Korea, Taiwan, Singapore, Hong Kong and mainland China (and to some extent, some of the Southeast Asian economies that used to be referred to as 'tiger cub economies').
} 
accelerated growth. This process of exposure is stressful and painful, and at some point, it is associated with discursive stigmatisation of being "lagged behind." - Another temporality, one that justifies and consolidates regional inequality, looms large here. In South Korea, citizens of economically stagnant regional cities despair at the impossible dream of re-living the high-speed growth they used to experience in the bygone developmental era. For people in these cities, their biggest concern often turns out to be whether or not any kind of investment, be it productive or conspicuous, would arrive at their localities - they thus become more expectant and accommodating of speculative investment despite potential harms to widening inequality and aggravating injustice. Urban injustice in such localities might means something different from how it would have been understood in global cities.

\section{Coda}

With reflections from/on Asia, this paper explores the economic, governing, and living status quo of 'fast urbanism'. We demonstrate that the 'Asian speed' of development was enabled in specific historical-geographical conjunctures, which could hardly be replicated, if at all. In addition, this model is risky for its political effects of erecting a new mode of governance that may restrict civil liberties and the right to the city. With the case of China in particular, we see vividly how 'the temporal impossibility of justice' is widely tolerated. This in turn renders possible new techniques of governance (or non-governance) that are more temporal (or at least temporality-related) than territorial. With the normalised expectation of speed, a certain kind of futurity is also created, which appropriates individual and collective aspirations and in so doing consolidates local politico-economic structures that displace both the present and the future.

In thinking about progressive urban futures, we may think of two different types of temporality, which compete with each other. On the one hand, there is the 'fast city' temporality, driven by the pressure of 'time-speed compression' to accelerate the process of industrialisation and urbanisation in order to realise value as fast as possible. On the other hand, there is a contrasting need to slow down the process of conventionally perceived economic development through a reconceptualisation of the existing framework of value extraction and appropriation. 'Slow cities movement' (Mayer and Knox, 2006) may be one of the small experiments that reconceptualise the relationship between development and time/speed. Enhancing inhabitants' participation in the process of planning and distributing social surplus can be another effort to rethink the pace of development. The politics of the urban, in this regard, is centring on the competition between two antagonistic temporalities of development that are playing out across geographies and generations.

In her discussion about Asia's developmental aspirations, Roy (2016, p.317) refers to Asia "as a set of citationary relations through which a politics of futurity is crafted." In this paper, we have built on her proposition to further investigate the politics of temporality that would play out across geographies and across generations. Perhaps the key question to ask, when thinking about urban futures in specific geographical and historical contexts, is this: What is the ideal speed here, in this place, at this moment in time - and how is it configured and widely accepted? The growing gaps and inequalities between places and between generations would eventually expose the contradictions of mindless and inequitable accumulation and the emptiness of hegemonic ideology that no longer suit the material conditions of societies. To advance towards progressive urban futures, perhaps what we need is to pause and reflect first, before we jump onto the bandwagon of speedy development at the expense of equitable politics.

\section{Acknowledgements}

The authors acknowledge financial support from the Tackling the UK's International Challenges 2018 grant (reference: IC3 $\backslash 100155$ ) provided by the British Academy. Hyun Bang Shin acknowledges the financial support from the National Research Foundation of Korea Grant funded by the Korean Government (NRF- 2017S1A3A2066514). Hyun Bang Shin also thanks the participants and audience at the following events where some of the arguments in this article were presented: Brown Bag seminar, Khazanah Research Institute, Kuala Lumpur (December 2019); International Journal of Urban and Regional Research Public Lecture, London 
(November 2019); International Workshop, Korea Research Institute for Human Settlements (August 2019).

\section{References}

Cartier, C. (2013). Uneven development and the time/space economy. In W. Sun \& Y. Guo (Eds.), Unequal China: Political Economy and the Cultural Politics of Inequality (pp. 77-90). London: Routledge.

Cheng, J. (2019). The deliverman who fell in Shanghai's rainstorm: Single child, best employee and a fatal electric shock. 20 August. Retrieved from https://www.sohu.com/a/ 334995001_120146415

Chien, S-S. and M.D. Woodworth (2018). China's urban speed machine: The politics of speed and time in a period of rapid urban growth. International Journal of Urban and Regional Research, 42(4), 723-737.

Chua, B.H. (2017). Liberalism Disavowed: Communitarianism and State Capitalism in Singapore. Ithaca: Cornell University Press.

Chua, B.H. (1997). Political Legitimacy and Housing: Stakeholding in Singapore. London: Routledge.

Datta, A. and A. Shaban (eds.) (2017). Mega-urbanization in the Global South: Fast Cities and New Urban Utopias of the Postcolonial State. London: Routledge.

Doucette, J. and B-G. Park (eds.) (2019). Developmentalist Cities? Interrogating Urban Developmentalism in East Asia. Leiden: Brill.

Dunford, M., and G. Yeung (2011). Towards Global Convergence: Emerging Economies, the Rise of China and Western Sunset. European Urban and Regional Studies, 18(1), 22-46.

Gimm, D-W. (2013). Fracturing Hegemony: Regionalism and State Rescaling in South Korea, 1961-71. International Journal of Urban and Regional Research, 37(4), 1147-1167.

Glassman, J. and Y-J. Choi. (2014). The Chaebol and the US Military-Industrial Complex: Cold War Geopolitical Economy and South Korean Industrialization. Environment and Planning A, 46(5), 1160-1180.

Harvey, D. (2005). A brief history of neoliberalism. Oxford: Oxford University Press.

Harvey, D. (1989). The condition of modernity: An enquiry into the origins of cultural change. Oxford: Blackwell.

Holliday, I. (2000). Productivist welfare capitalism: Social policy in East Asia. Political Studies, 48(4), 706-723.

Lee, C.K. (2018). The specter of global China: Politics, labor, and foreign investment in Africa. Chicago and London: The University of Chicago Press.

Mallaby, S. (1995). South Korea: Quick, quick, quick. The Economist, 3rd June.

Mayer, H. and P.L. Knox (2006). Slow cities: Sustainable places in a fast world. Journal of Urban Affairs, 28(4), 321-334.

McCann, E. and K. Ward (eds.) (2011). Mobile Urbanism: Cities and Policymaking in the Global Age. Minneapolis: University of Minnesota Press 
Obarrio, J. (2012). "Theory from the South." Theorizing the Contemporary. Fieldsights, 24 February. Retrieved from https://staging.culanth.org/fieldsights/series/theory-from-the-south

Rodan, G. (1992). Singapore: Emerging Tensions in the "Dictatorship of the Middle Class". The Pacific Review, 5(4), 370-381.

Roy, A. (2005). Urban informality: toward an epistemology of planning. Journal of the American Planning Association, 71(2), 147-158.

Roy, A. (2009). Why India cannot plan its cities: Informality, insurgence and the idiom of urbanization. Planning theory, 8(1), 76-87.

Roy, A. (2016). When Is Asia? The Professional Geographer, 68(2), 313-321.

Shin, H.B. (2019) Asian urbanism. In: A.M. Orum (ed.) The Wiley-Blackwell Encyclopedia of Urban and Regional Studies. Wiley-Blackwell. URL: https://doi.org/ 10.1002/9781118568446.eurs0010

Shin, H.B. (2018) Urban movements and the genealogy of urban rights discourses: The case of urban Protesters against redevelopment and displacement in Seoul, South Korea. Annals of the American Association of Geographers, 108(2), 356-369

Shin, H.B. and Y. Zhao (2018). Urbanism as a state project: Lessons from Beijing's Green Belt. In M. Jayne (Ed.), Chinese Urbanism: Critical Perspectives (pp. 46-62). London and New York: Routledge.

Sidaway, J.D., E.L. Ho, J.D. Rigg \& C.Y. Woon (2016). Area studies and geography: Trajectories and manifesto. Environment and Planning D: Society and Space, 34(5), 777-790.

Simone, A. and E. Pieterse (2017). New Urban Words: Inhabiting Dissonant Tmes. Cambridge: Polity Press.

Smith, N. (1984). Uneven Development: Nature, Capital, and the Production of Space. Oxford: Blackwell.

Standing, G. (2011). The Precariat: The New Dangerous Class. London: Bloomsbury.

Teo, Y. (2011). Neoliberal morality in Singapore: How family policies make state and society. London: Routledge.

Wu, F. (2018). Planning centrality, market instruments: Governing Chinese urban transformation under state entrepreneurialism. Urban Studies, 55(7), 1383-1399.

Wu, F. (2015). Planning for Growth: Urban and Regional Planning in China. Abingdon, Oxon: Routledge.

$\mathrm{Xi}$, J. (2012). Carry forward the past, move towards the future, and continue forging ahead towards the goal of "the Great Rejuvenation of the Chinese nation", 29 November. Retrieved from http://www.xinhuanet.com//politics/2012-11/29/c_113852724.htm

Yang, X. (2019). Ma Yun talks about 996: "It is a blessing to be able to work in 996 style, while there are many people who would like to but have no chance". Pengpai News, 12 April. Retrieved from https://www.thepaper.cn/newsDetail forward 3291793

Zhang, L. and A. Ong (eds.) (2008). Privatizing China: Socialism from afar. Ithaca: Cornell University Press.

Zhao, Y. (2017). The hegemony of urbanisation: Questioning the production of space by the state in Beijing's green belts. Unpublished doctoral dissertation, The London School of Economics and Political Science. 